Acta vet. scand. 1971, 12, 230-242.

From the Research Station of the Veterinary Institute, Skara, Sweden.

\title{
STUDIES OF THE BLOOD LIPID PATTERN IN HEALTHY DAIRY COWS
}

\author{
By \\ Bo Pehrson
}

The interest in the blood lipid pattern has greatly increased since in the last few years research has established that the adipose tissue plays an important part in the physiological and pathological metabolism of mammals. As far as dairy cows are concerned, charting of the various blood lipids has been done only to a limited extent. This applies even under physiological conditions.

Varying with breed and stage of lactation plasma or serum from normal dairy cows contains $200-600 \mathrm{mg}$ total lipids per $100 \mathrm{ml}$ (cf. Maynard et al. 1931; Riis 1964; Storry \& Rook 1964; Leat 1967). The main proportion ( $85-90 \%)$ consists of roughly equal parts of phospholipids and cholesterol. Independent of the stage of lactation, $75-90 \%$ of the total cholesterol exists in esterified form. Apart from the quantitatively dominating phospholipids and cholesterol fractions the lipids in the blood of cows consist in normal cases of less than $10 \%$ triglycerides and less than $5 \%$ non-esterified fatty acids (NEFA). There are also quantitatively insignificant amounts of other lipids, e.g. carotinoids and fat-soluble vitamins.

As regards phospholipids and cholesterol it has been established that serum samples can be kept for at least one day at room temperature and in a refrigerator (Henry 1966). Nor should the result of the analysis be affected by deep-freezing. There is no (Shaible 1932; Platikanoff 1933; Lennon \& Mixner 1957) or as regards cholesterol only a slight (Unshelm 1969) diurnal variation of these parameters in healthy dairy cows, but a pro- 
nounced variation with the stage of lactation. A number of studies thus indicate distinctly that a marked lowering both of the phospholipid and cholesterol values takes place at calving and/or that the values during dry-period are lower than during lactation (Maynard et al.; Shaible; Lennon \& Mixner; Riis; Storry \& Rook 1964; Leat; Varman \& Schultz 1968). The prepartal levels are obtained a couple of days after calving, and from the studies of Maynard et al. and Riis it appears as if the highest values occur at maximal daily yield.

Thus, whereas the physiological conditions for phospholipids and cholesterol in dairy cows are satisfactorily known, the same cannot be said of NEFA and triglycerides. The object of the present work was, through supplementary studies, to establish the measures in conjunction with sampling and storage that are necessary for NEFA and triglyceride analyses to yield representative values, and the variations, if any, in these parameters that exist diurnally and with stage of lactation. The content of free glycerol in serum has also been taken into account in these respects, which does not appear to have been done earlier within veterinary medicine. As glycerol is released in parallel with NEFA on breakdown of triglycerides in adipose tissue (Mueller \& Evans 1963), serum glycerol in addition to NEFA determinations should give a good picture of the degree of fat mobilization. The magnitude of the fat mobilization is partly dependent on the quantity of glucose available for the living cells. In the event of a negative energy balance in ruminants there is both a lowering of the blood glucose content (Storry \& Rook 1962; Patterson et al. 1964; Pehrson 1966) and an elevation of NEFA (Patterson et al.; Russel et al. 1967) and presumably glycerol in serum. To illustrate which of these parameters may constitute the most sensitive measure of variations in the nutritional balance, blood glucose analyses were also made for varying levels of yield.

\section{MATERIAL AND METHODS}

The material consisted of Swedish red-and-white cows of one herd. The cows were fed twice a day (6 a.m. and 2 p.m.) and the ration was available for about $4 \mathrm{hrs}$. With the exception of the investigation of diurnal variation, blood samples were taken 2.5 - 4 hrs. after the morning feed. (However, in the investigation of the effect of refrigeration and deep-freezing on the analytical 
results, some of the cows had been without feed for nearly 24 hrs.). Centrifugation was done as soon as possible, and in all cases within $45 \mathrm{~min}$. after sampling. The analysis was started as soon as possible after centrifugation, or serum was deep-frozen immediately and then kept at about $-20^{\circ} \mathrm{C}$. For comparison between samples drawn and centrifuged at room temperature and in cold, refrigerated tubes were used in the latter case and, after sampling; were kept and centrifuged at about $4^{\circ} \mathrm{C}$. In the investigation of diurnal variation the blood samples marked 6 a.m. and 2 p.m. in Fig. 1 were drawn immediately before feeding.

The following methods of analysis were used:

NEFA in serum according to Laurell \& Tibbling (1967) using serum instead of plasma. This colorimetric micromethod is based on the formation of NEFA-Cu soaps and, in contrast to the titrimetric method of Dole (1956), is not appreciably interfered with by lactic acid, acetate, acetone, $\beta$-hydroxybutyrate or isopropanol (own observations).

Free glycerol in serum according to Eggstein \& Kreutz (1966) using Firma Boehringer's standard method.

Triglycerides in serum according to Laurell (1966).

Blood glucose using glucose oxidase according to the standard method of AB Kabi, Stockholm.

\section{RESULTS}

There were no significant differences in the NEFA and glycerol values in serum between samples drawn in refrigerated tubes and centrifuged in cold and samples drawn and centrifuged at room temperature (Table 1 ). The differences between these samples were not greater than those obtained in determination of the error of the method.

Table 1. NEFA and free glycerol in serum after sampling and centrifugation at refrigerator temperature and at room temperature.

\begin{tabular}{|c|c|c|c|c|}
\hline & \multicolumn{2}{|c|}{ NEFA, $\mathrm{mmol} / \mathrm{l}$} & \multicolumn{2}{|c|}{ Glycerol, mg/100 ml } \\
\hline & refrigerated & room temp. & refrigerated & room temp. \\
\hline $\mathrm{n}$ & 8 & 8 & 8 & 8 \\
\hline$\overline{\mathbf{x}}$ & 0.530 & 0.560 & 0.326 & 0.323 \\
\hline $\mathbf{s}$ & 0.280 & 0.271 & 0.136 & 0.132 \\
\hline $\mathrm{t}$ & \multicolumn{2}{|c|}{0.22} & \multicolumn{2}{|c|}{0.04} \\
\hline
\end{tabular}


T a ble 2. NEFA, free glycerol and triglycerides in serum before and after deep-freezing for 1 week and 5 months.

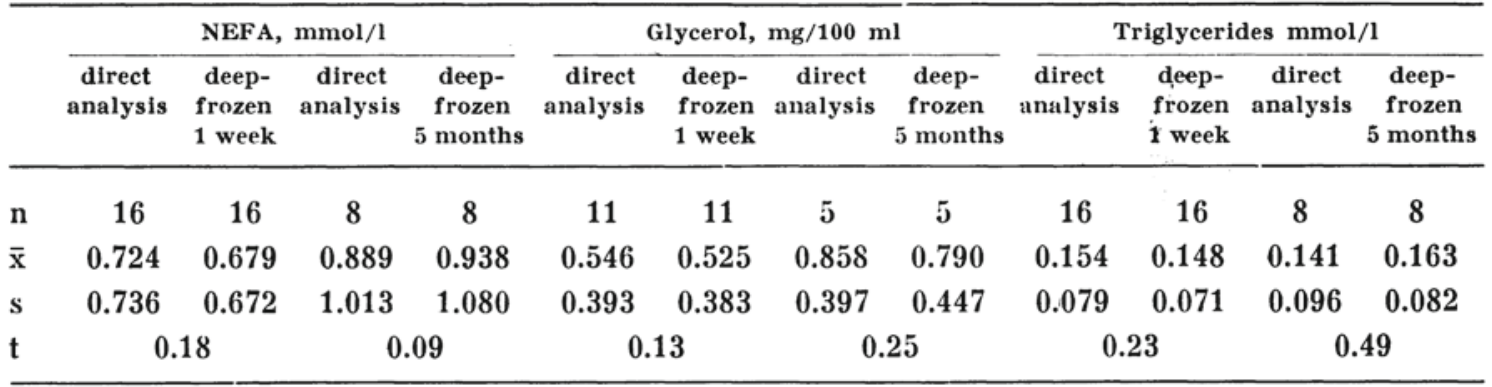

Deep-freezing of serum for one week and 5 months did not significantly affect the values of NEFA, glycerol and triglycerides (Table 2). Nor in these cases were the measured differences greater than in the investigation of the error of the method.

It will be seen from Fig. 1 that a significant diurnal variation occurred for NEFA and glycerol but not for triglycerides. The highest values were measured both for NEFA and glycerol before

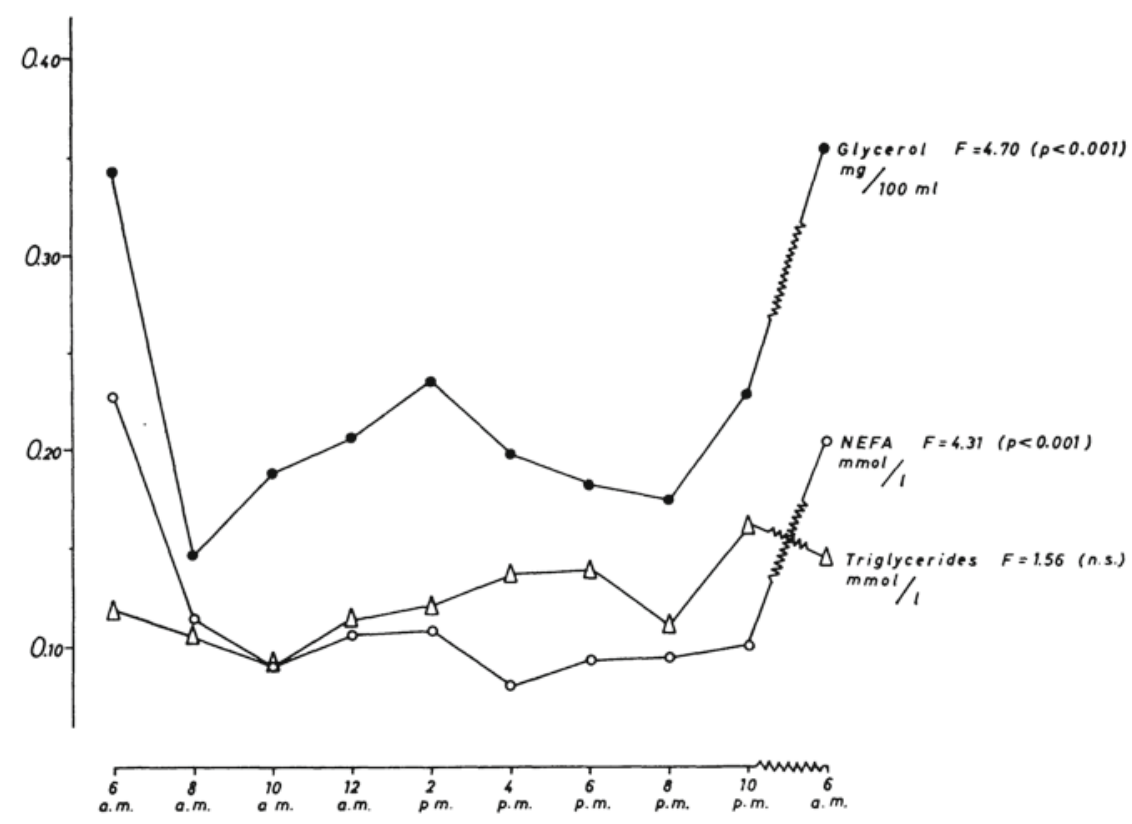

F i g u r e 1. Diurnal variation for NEFA, free glycerol and triglycerides in serum from healthy dairy cows fed immediately after sampling at 6 a.m. and 2 p.m. Mean for 12 cows. 
feeding at 6 a.m., when the cows had been without feed for about 12 hrs. For glycerol the values before feeding at 2 p.m., when the cows had been without feed for 3-4 hrs., were significantly $(0.05>\mathrm{P}>0.01)$ different from those measured at 8 a.m. No corresponding significant difference occurred for NEFA.

The variation of the parameters with the daily yield is shown in Fig. 2, which includes no production figures during the period 21 days before to 30 days after calving. The NEFA content was highest at a production level exceeding $25 \mathrm{~kg}$ per day and was then significantly higher $(0.01>\mathrm{P}>0.001)$ than at a production of $1-25 \mathrm{~kg}$ per day. The glycerol values were significantly higher $(\mathrm{P}<0.001)$ during the dry-period than when the cows produced $1-25 \mathrm{~kg}$. The glucose values were numerically lowest at the highest production level and were then significantly lower $(0.05$ $>\mathrm{P}>0.01$ ) than in dry cows. The triglyceride content was significantly higher $(\mathrm{P}<0.001)$ during the dry period than during lactation.

Fig. 3 shows variations during the most interesting part of the lactation year from the point of view of lactation diseases, i.e. 3 weeks before to one month after calving. With few exceptions there were higher serum contents of NEFA and glycerol throughout this period than during the remainder of the lactation year (Fig. 2). During the period 4 days before to 30 days after

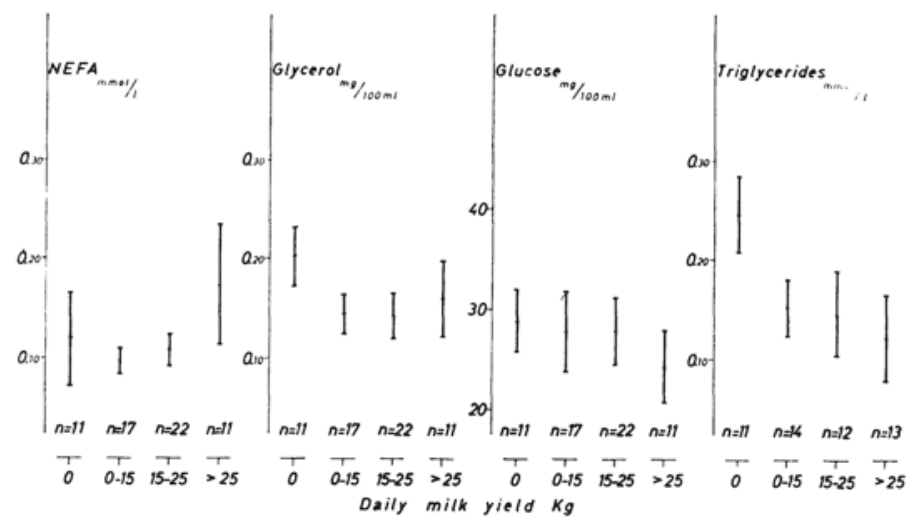

Figure 2. NEFA, free glycerol, glucose and triglycerides in serum and whole blood (glucose) from healthy dairy cows for different daily yields. No production figures during the period 21 days before to 30 days after calving are included. Sampling $2.5-4 \mathrm{hrs}$. after morning feed. Mean $\pm 95 \%$ confidence interval. 


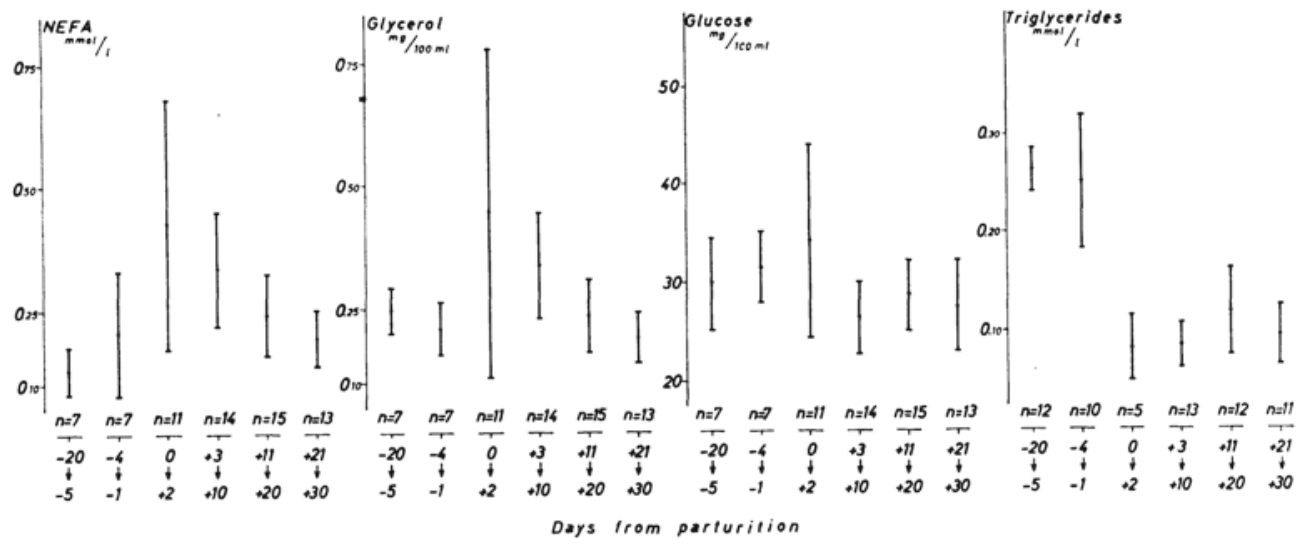

F i g u re 3. NEFA, free glycerol, glucose and triglycerides in serum and whole blood (glucose) from healthy dairy cows during the period 21 days before to 30 days after calving. Sampling 2.5-4 hrs. after morning feed. Mean $\pm 95 \%$ confidence interval.

calving the values for NEFA and glycerol behaved similarly with the highest average values on the first two days after calving, after which a successive drop occurred. Analysis of variance showed that the measured variations as illustrated in Fig. 2 were significant $(0.05>\mathrm{P}>0.01)$ for NEFA, whereas a significant level was not achieved for glycerol. Student's t-test, however, showed that the glycerol content during the period $3-10$ days after calving was significantly $(0.05>\mathrm{P}>0.01)$ higher than during the period $21-30$ days after calving. The blood glucose values were numerically higher during the first two days after calving and lower during the first week of lactation than during the remainder of the period. The triglyceride content was significantly higher $(\mathrm{P}<0.001)$ before than after calving.

\section{DISCUSSION}

It has previously been shown that carefully standardized sampling and analysis procedures are necessary for ensuring correct values of NEFA in serum or plasma. It is thus necessary that the blood samples are drawn quickly and without preceding unnecessary irritation of the animal, as otherwise the NEFA content rises as a result of fat mobilization through nervous influence (Patterson 1963). It has also been found that the NEFA content rises quickly if the serum or plasma is stored too long 
or under unsuitable conditions. Henry (1966) reports that storage at $25-30^{\circ} \mathrm{C}$ for $6 \mathrm{hrs}$. results in an increase of $16 \%$ and in a refrigerator for $24 \mathrm{hrs}$. in an increase of $12-25 \%$.

For glycerol there are no corresponding data in the literature concerning the significance of quickly performed sampling and analysis. As for NEFA, however, the glycerol level should rise with fat mobilization through nervous influence, for which reason undisturbed sampling is probably necessary. If the increase in NEFA content which occurs on storage is due to breakdown of triglycerides through lipoprotein lipase in the serum or plasma, a corresponding increase of the glycerol content should take place and equally rapidity as in NEFA analysis would be necessary. This need not be the case, however, if the NEFA increase is instead caused by a conversion of lecithin to lysolecithin, as intimated by Henry.

Fairweather \& Layton (1967) studied the effect of different sampling and preparatory measures for NEFA analysis and drew the conclusion that one should use heparinized and refrigerated tubes. The experimental results reported in this paper, however, show that determinations of the serum content of NEFA and free glycerol can be done on blood samples drawn in non-refrigerated tubes and centrifuged at room temperature within 45 min. They also show that if the samples are deep-frozen as soon as possible, storage at about $-20^{\circ} \mathrm{C}$ can take place for a long period without significantly affecting the results of the analysis. This is in contrast to the statement of Forbes \& Camlin (1959) that NEFA increased by 12-50 \% after 24 hrs.' storage in deepfrozen state, but accords with the statements made by Gordon et al. (1957) and Kronfeld (1965).

It will be evident from the above that there should be fairly good prospects of using material collected in ambulatory practice for NEFA and glycerol analyses. If the time from sampling to centrifugation is more than $45 \mathrm{~min}$., which should happen only in exceptional cases, it is absolutely necessary that the samples are cooled down to refrigerator temperature immediately after being drawn (own unpublished observations). If the samples are kept for more than $4 \mathrm{hrs}$. without being deep-frozen, there will probably be altogether too great an effect on the analysis values, which appears to apply at least for NEFA (Henry).

Deep-freezing of serum for 5 months did not affect the triglyceride values (Table 2). It has previously been found that the 
triglycerides are durable at least for a day or so during storage of serum at room temperature (Henry).

Russel et al. (1967) reported that in sheep fed once daily there was a diurnal variation for plasma NEFA. The values were very much lower $2-3$ hrs. after than before feeding. Kronfeld investigated serum NEFA in two normal cows every third hour for one day and found that the content was highest before the two feeds and lowest $3 \mathrm{hrs}$. after. Kronfeld's findings are entirely confirmed by the results in Fig. 1, which suggest that mobilization of body fat is positively correlated to the time during which the animals have been without feed. The results also accord closely with those reported by Russel et al. After feeding, the fat mobilization appears to diminish or cease very quickly. The serum content of glycerol appears to constitute a comparatively more sensitive measure of the mobilization of body fat as NEFA, as appears from the fact that the withholding of feed for 3-4 hrs. was sufficient to cause a significant increase in the glycerol but not in the NEFA content.

The large diurnal variations for NEFA and glycerol imply that great care must be taken in the choice of sampling time. The sampling time should have no effect, on the other hand, in determination of the serum content of triglycerides, since no significant diurnal variation was found (Fig. 1).

From Figs. 2 and 3 it will be seen that the NEFA and glycerol values in serum vary with the daily yield and during the period one month before to one month after calving. In view of the more intensive metabolism and the increasing difficulties of achieving an energy balance with rising yield, one should expect a greater fat mobilization and consequently higher values of NEFA and glycerol the higher the production level is. This happened for NEFA. For glycerol, on the other hand, the values were numerically higher during the dry-period than at the time of highest production, and significantly higher than at a production of $1-25 \mathrm{~kg}$ per day (Fig. 2). The reason for this is unknown. It appears out of the question that the comparatively high glycerol values during the dry-period were caused by an increased mobilization of body fat consequent on a negative energy balance, since the feeding during the dry-period in this herd was so abundant that the cows tended to become overfat at the time of calving.

During the first month of lactation the NEFA and glycerol 
values showed a great mutual parallelism (Fig. 3). The values during this period were considerably higher than during the remaining lactation period (Fig. 2). This was in all probability a result of greater mobilization of body fat, which can be explained both by the fact that good milk producers so quickly after calving achieve a high daily yield that some underfeeding is virtually inevitable during the first weeks of lactation (Pehrson 1966), and that it appears to be a physiological phenomenon that female animals lose weight during the first period after parturition (Lenkeit et al. 1956). That the NEFA and glycerol values successively diminished from the first week of lactation may be explained largely by the fact that the energy supply via the feed increasingly approached the energy losses through the milk production, so that the need for mobilization of energy from body fat diminished. The very great variations in the NEFA and glycerol values which occurred during the first two days after calving were probably due to the drawing of the samples at different times (range from 1 to 40 hrs. after calving). If sampling had been consistently done during the first hrs. after calving, the values would probably have been higher throughout owing to the sympathicotonia which occurs in conjunction with calving (Whaley et al. 1967). For an increased incretion of catecholamines very quickly gives rise to an increased mobilization of body fat (cf. Mueller \& Evans 1963; Brodie et al. 1965).

As regards blood glucose there were tendencies to higher values during the first two days after calving and lower during the first week of lactation and at the highest production level (Figs. 2 and 3 ). This agrees with the conclusions drawn from the variations for NEFA and glycerol, since an increased sympathetic tonus in conjunction with calving should increase the glucose content, while a negative energy balance should reduce it. Since the lowering of glucose content was considerably less than the increase of NEFA and glycerol, however, it seems as if determination of the blood glucose content is a less sensitive measure of the energy balance. This agrees with conclusions which can be drawn from previous experiments with sheep by Reid \& Hinks (1962) and Patterson et al. (1964).

The triglyceride content in serum has previously been reported to be lowered in conjunction with calving, while no difference was found between dry and lactating cows (Leat 1967). In contradistinction thereto, but in agreement with the findings 
of Storry \& Rook (1964) and Varman \& Schultz (1968) the triglyceride values in the present investigation were distinctly higher during the dry period than during lactation. No significant differences existed between different production levels or during different stages of the dry period. It appears, therefore, as if the triglyceride level in serum is dependent on whether milk secretion occurs or not, and does not appreciably vary with production level or energy balance.

\section{REFERENCES}

Brodie, B. B., R. P. Maicket \& D. N. Stern: Autonomic nervous system and adipose tissue. In Handbook of Physiology, Section 5: Adipose Tissue. Amer. physiol. Soc., Washington D.C. 1965, $583-600$.

Dole, V. P.: A relation between non-esterified fatty acids in plasma and the metabolism of glucose. J. clin. Invest. 1956, 35, 150-154.

Eggstein, M. \& F. H. Kreutz: Eine neue Bestimmung der Neutralfette im Blutserum und Gewebe. (A new method for determination of triglycerides in serum and tissues). Klin. Wschr. 1966, 44, $262-267$.

Fairweather, D. V. I. \& R. Layton: Observations on the collection and handling of blood samples for N.E.F.A. estimation. J. clin. Path. 1967, 20, 665-667.

Forbes, A. L. \& J. A. Camlin: Effects of storage on serum non-esterified fatty acid concentrations. Proc. Soc. exp. Biol. (N.Y.) 1959, 102, 709-710.

Gordon, R. S. jr., A. Cherkes \& H. Gates: Unesterified fatty acid in human blood plasma. II. The transport function of unesterified fatty acid. J. clin. Invest. 1957, $36,810-815$.

Henry, R. J.: Clinical chemistry, ed. Harper \& Row, New York, Evanston \& London 1966.

Kronfeld, D. S.: Plasma non-esterified fatty acid concentrations in the dairy cow: Responses to nutritional and hormonal stimuli, and significance in ketosis. Vet. Rec. 1965, 77, 30-35.

Laurell, $S$.: A method for routine determination of plasma triglycerides. Scand. J. clin. Lab. Invest. 1966, 18, 668-672.

Laurell, S. \& G. Tibbling: Colorimetric micro-determination of free fatty acids in plasma. Clin. chim. Acta 1967, 16, 57-62.

Leat, W. M. F.: Plasma lipids of newborn and adult ruminants and of lambs from birth to weaning. J. agric. Sci. 1967, 69, 241-246.

Lenkeit, W., J. O. Gütte, W. Kirchhoff, F. K. Soehngen \& E. Farries: Weitere Untersuchungen zur Abhängigkeit des N-Umsatzes während der Laktation von der Nährstoffversorgung während der Gravidität. IV. (Further investigations on the correlation between nitrogen metabolism during lactation and the supply of nutrients during pregnancy. IV). Z. Tierernähr. Futtermittelk. $1956,11,337-352$. 
Lennon, H. D. \& I. P. Mixner: Some sources of variation in total plasma cholesterol levels in dairy cattle. J. Dairy Sci. 1957, 40, 14241429.

Maynard, L. A., E. S. Harrison \& C. M. McCay: The changes in the total fatty acids, phospholipid fatty acids and cholesterol of the blood during the lactation cycle. J. biol. Chem. 1931, 92, 263-272.

Mueller, P. S. \& W. H. Evans: Responses of plasma glycerol concentrations to epinephrine, norepinephrine, glucose, insulin, and prolonged fasting in man. J. Lab. clin. Med. 1963, 61, 953-961.

Patterson, D. S. P.: Some observations on the estimation of non-esterified fatty acid concentrations in cow and sheep plasma. Res. Vet. Sci. 1963, 4, 230-237.

Patterson, D. S. P., K. N. Burns, N. F. Cunningham, C. N. Hebert \& N. Saba: Plasma concentrations of glucose and non-esterified fatty acids (NEFA) in the pregnant and lactating ewe and the effect of dietary restriction. J. agric. Sci. 1964, 62, 253-262.

Pehrson, B.: Studies on ketosis in dairy cows. Acta vet. scand. 1966, 7, suppl. 15.

Platikanoff, N.: Die Lipoidstoffe im Blutserum des Rindes. (Serum lipids in dairy cattle). Z. Zücht. 1933, 26, 1-36.

Reid, R. L. \& N. T. Hinks: Studies on the carbohydrate metabolism of sheep. XVIII. The metabolism of glucose, free fatty acids, ketones and amino acids in late pregnancy and lactation. Aust. J. agric. Res. 1962, 13, 1112-1123.

Riis, P. M.: Investigations on lipid metabolism in cattle. Thesis. Copenhagen 1964.

Russel, A.J.F., J. M. Doney \& R. L. Reid: The use of biochemical parameters in controlling nutritional state in pregnant ewes, and the effect of undernourishment during pregnancy on lamb birth-weight. J. agric. Sci. 1967, 68, 351-358.

Shaible, J. P.: Plasma lipids in lactating and non-lactating animals. J. biol. Chem. 1932, 95, 79-88.

Storry, J.E. \& J. A. F. Rook: The effect of level of feeding before and after calving on the concentration of plasma glucose in the cow. Proc. Nutr. Soc. 1962, 21, 39-40.

Storry, J. E. \& J. A. F. Rook: Lipids in the blood plasma of cows of the Friesian and Channel Island Breeds. Nature (Lond.) 1964, $201,926$.

Unshelm, J.: Individuelle, tages- und tageszeitabhängige Schwankungen von Blutbestandteilen beim Rind. 5. Mitteilung: Das Verhalten der Spurenelemente Eisen und Kupfer sowie des Cholesterins. (Individual, diurnal and time-of-day changes in the blood constituents of cattle. 5. Behaviour of the trace elements iron and copper and cholesterol). Zbl. Vet.-Med. Reihe A, 1969, $16,703-711$.

Varman, P. N.\& L. H. Schultz: Blood lipids of cows at different stages of lactation. J. Dairy Sci. 1968, 51, 1971-1974. 
Whaley, W. H., F. P. Zuspan, G. H. Nelson \& R. P. Ahlquist: Alterations of plasma free fatty acids and glucose during labor. Amer. J. Obstet. Gynec. $1967,97,875-880$.

\section{SUMMARY}

The object was to add to the knowledge of certain blood parameters of significance for charting the lipid metabolism in dairy cows. The result may be summarized as follows:

1. Determination of the serum content of NEFA and free glycerol could be done on blood samples drawn in non-refrigerated tubes and centrifuged at room temperature within $45 \mathrm{~min}$. Deep-freezing of serum did not affect the results of the analysis for these parameters.

2. A significant diurnal variation occurred for NEFA and free glycerol. The highest values were measured in the morning, when the cows had been without feed for about $12 \mathrm{hrs}$. For glycerol (but not for NEFA) the values in the afternoon, when the cows had been without feed for 3-4 hrs., were significantly higher than those taken 2 hrs. after the morning feed.

3. NEFA and free glycerol varied significantly with the daily yield. The NEFA content was highest at the highest level of yield, while the glycerol values were highest during the dry-period. The investigations reported under point 3 , however, included no production figures during the period 21 days before to 30 days after calving.

4. During the first month of lactation the NEFA and glycerol values showed a great mutual parallelism. The values during the first weeks of lactation were considerably higher than during the remaining lactation periods, which in all probability is a result of inevitable underfeeding of cows with good milking predisposition.

5. During the first two days after calving there were very great variations in NEFA and free glycerol. If sampling had been consistently done during the first hrs. after calving, the values would probably have been higher throughout owing to the sympathicotonia which occurs at that time.

6. In general, blood glucose varied less than NEFA and free glycerol with the level of yield. Thus, it seems as if blood glucose is a less sensitive measure of the energy balance.

7. Deep-freezing of serum did not affect the values of triglycerides. No significant diurnal variation occurred for this parameter. The triglyceride values were distinctly higher during the dry-period than during lactation. No significant differences existed, however, between different production levels or during different stages of the dry-period.

\section{SAMMANFATTNING}

Undersökningar av blodlipidmönstret hos friska mjölkkor.

Avsikten var att komplettera kännedomen om vissa blodparametrar, vilka är av betydelse för kartläggning av fettmetabolismen hos mjölkkor. Av undersökningen framgick: 
1. Bestämningar av serumhalten icke förestrade fettsyror (NEFA) och fri glycerol kunde med tillfredsställande noggrannhet utföras på blodprov som togs $\mathrm{i}$ icke kylda rör och som centrifugerats vid rumstemperatur inom 45 minuter. Djupfrysning av serum påverkade inte analysresultaten för dessa parametrar.

2. Signifikant dygnsvariation förelåg för NEFA och fri glycerol. De högsta värdena uppmättes före morgonutfodringen, då korna varit utan foder c:a 12 timmar. För fri glycerol (men ej för NEFA) var värdena före eftermiddagsutfodringen, då korna varit utan foder 3-4 timmar, signifikant högre än 2 timmar efter morgonutfodringens början.

3. NEFA- och fri glycerol varierade signifikant med dygnsavkastningen. För NEFA förelåg de högsta värdena vid den högsta produktionsnivån, medan de högsta glycerolvärdena uppmättes under sintiden. Vid de undersökningar som redovisas under 3 . medtogs dock inga produktionssiffror under tiden 21 dagar före till 30 dagar efter kalvningen.

4. Under den första månaden efter kalvningen visade NEFA- och glycerolvärdena stor inbördes parallellitet. Värdena under de första laktationsveckorna var betydligt högre än under övriga laktationsperioder, vilket tolkas som en följd av en oundviklig underutfodring hos kor med goda mjölkanlag.

5. Under de båda första dagarna efter kalvningen förelåg mycket stora variationer i NEFA- och glycerolvärden. Det antages att konsekvent provtagning i mer omedelbar anslutning till partus hade givit genomgående högre värden till följd av då föreliggande sympaticotoni.

6. Blodglykoshalten varierade $\mathrm{i}$ allmänhet mindre med avkastningsnivån än vad som gällde för NEFA och fri glycerol. Med anledning härav drages slutsatsen att blodglykos utgör ett mindre känsligt mått på energibalansen.

7. Djupfrysning av serum påverkade inte triglyceridhalten. Signifikant dygnsvariation förelåg inte för serumtriglycerider. Triglyceridvärdena var entydigt högre under sintiden än när korna mjölkade. Däremot förelåg inga skillnader mellan olika produktionsnivåer eller under olika stadier av sinperioden.

(Received March 28, 1970). 